\title{
A Review on Red Rot: The "Cancer" of Sugarcane
}

\section{Ruchika Sharma and Sushma Tamta*}

Department of Biotechnology, Plant Tissue Culture and Molecular Biology Laboratory, Bhimtal Campus, Kumaun University, Nainital, Uttarakhand-263136, India

\begin{abstract}
Sugarcane is an important agro industrial crop of the world. India being the largest consumer as well as the second largest producer of sugar, so, it requires sugarcane production on large scale. But diseases are the major concern for the sugarcane, responsible for its low yield. Among all the diseases, fungal disease named red rot of sugarcane is the most threatening disease of sugarcane, rightly called as 'Cancer' of sugarcane. It causes severe loss in yield and quality of the sugarcane. As the fungus Colletotrichum falcatum responsible for this disease is highly variable in nature, hence, it causes the frequent breakdown of resistant varieties. Keeping in view the seriousness of this disease, the present review summarizes the distribution, mode and source of infection, description of casual pathogen and disease management.
\end{abstract}

Keywords: Colletotrichum falcatum, Saccharum spp.; Cancer; Dissemination; Resistance

\section{Introduction}

Saccharum spp. (Sugarcane) is an important cash crop cultivated in tropical and sub- tropical regions of the world. It is valuable mainly because of its ability to store high concentrations of sucrose, or sugar, in the stem and more recently for the production of ethanol, which is an important renewable biofuel source [1,2]. Globally, sugarcane is an important source of commercial sugar accounting for almost twothirds of world sugar production [1]. Brazil is the largest sugarcane producer, contributing with $40 \%$ of the world production, followed by India, China, Thailand, Pakistan, Mexico, Philippines, United States, Australia and Argentina [3]. The list of top ten sugarcane producing countries with their estimated sugarcane production in the year 2011 is listed in Table 1.

Sugarcane is cultivated in most of the states of India with total area coverage of 4.2 million hectare ( $\mathrm{M} \mathrm{ha}$ ). It is the second most important agro industrial crop in India, next only to cotton [4]. The sugarcane producing states of India and their contribution in sugarcane production is shown in Figure 1. India is the largest consumer of sugar in the world with annual consumption of about 19 million MT (Metric Tons) and the second largest producer of sugar next to Brazil, with production of sugar crossing 28 million MT in India in year 200910 [5] and with increasing population needs, sugarcane production requires enhancement [6]. However various biotic and abiotic factors are responsible for its low yield, diseases are the major cause of concern. About hundred diseases of sugarcane have been reported from different parts of the world [7]. Over 100 fungi, 10 bacteria, and 10 viruses and about 50 species of nematodes are pests of sugarcane in different parts of the world [8].

In India, the estimated loss in crop production due to fungal diseases is about $18-31 \%$ [4]. Losses due to sugarcane diseases are shown in Figure 2. Red rot is the most common disease of sugarcane, caused by the fungus Colletotrichum falcatum Went. It causes severe loss in yield and quality of the susceptible cultivars in the Indian subcontinent $[9,10]$. It can reduce cane weight by up to $29 \%$ and loss in sugar recovery by $31 \%$ [11]. Red rot pathogen hydrolysed the stored sucrose by producing the enzyme invertase which breaks the sucrose molecule into its components namely glucose and fructose. As a result the quantity of molasses increases [12]. It is aptly called the "Cancer" of sugarcane [13].

Red rot is also the oldest mentioned disease of sugarcane dating back to the times of Buddha. The disease was first reported from Java, Indonesia, where it was known as "Sereh" [14] and generally known to cause by the fungus, $C$. falcatum Went. The perfect stage of the fungus was identified as Physalospora tucumanesis Speg. [15] and finally known as Glomerella tucumanesis Speg. [16]. Barber Ca [17] recorded the first report of red rot occurrence in India. Since then a number of red rot epidemics have been reported, especially in eastern Uttar Pradesh, northern Bihar and pockets of Punjab. These epidemics have resulted in failure of some important Indian commercial sugarcane varieties [18-20].

\section{Epidemiology}

\section{Sources of infection}

Red rot can infect mature stalks of sugarcane, leaf mid ribs and cause rot of planting material which results in substantial losses in crop

\begin{tabular}{|c|c|}
\hline Country & Production (TMT*) \\
\hline Brazil & 734,000 \\
\hline India & 342,382 \\
\hline People's Republic of China & 115,124 \\
\hline Thailand & 95,950 \\
\hline Pakistan & 55,309 \\
\hline Mexico & 49,735 \\
\hline Philippines & 34,000 \\
\hline United States & 26,656 \\
\hline Australia & 25,182 \\
\hline Argentina & 25,000 \\
\hline World & $\mathbf{1 , 7 9 4 3 5 9}$ \\
\hline TMT: Trillion Metric Tons & \\
\hline
\end{tabular}

Table 1: Top ten sugarcane producers: 2011 (Source: Food and Agricultural Organization of United Nations: Economic And Social Department: The Statistical Division).

*Corresponding authors: Sushma Tamta, Plant Tissue Culture and Molecular Biology Laboratory, Department of Biotechnology, Bhimtal Campus, Kumaun University, Nainital, Uttarakhand-263136, India, Tel: +919412924956; E-mail: sushmatamta@gmail.com

Received April 29, 2015; Accepted May 21, 2015; Published June 15, 2015

Citation: Sharma R, Tamta S (2015) A Review on Red Rot: The "Cancer" of Sugarcane. J Plant Pathol Microbiol S1: 003. doi:10.4172/2157-7471.S1-003

Copyright: $\odot 2015$ Sharma R, et al. This is an open-access article distributed under the terms of the Creative Commons Attribution License, which permits unrestricted use, distribution, and reproduction in any medium, provided the original author and source are credited. 
Citation: Sharma R, Tamta S (2015) A Review on Red Rot: The "Cancer” of Sugarcane. J Plant Pathol Microbiol S1: 003. doi:10.4172/2157-7471. S1-003

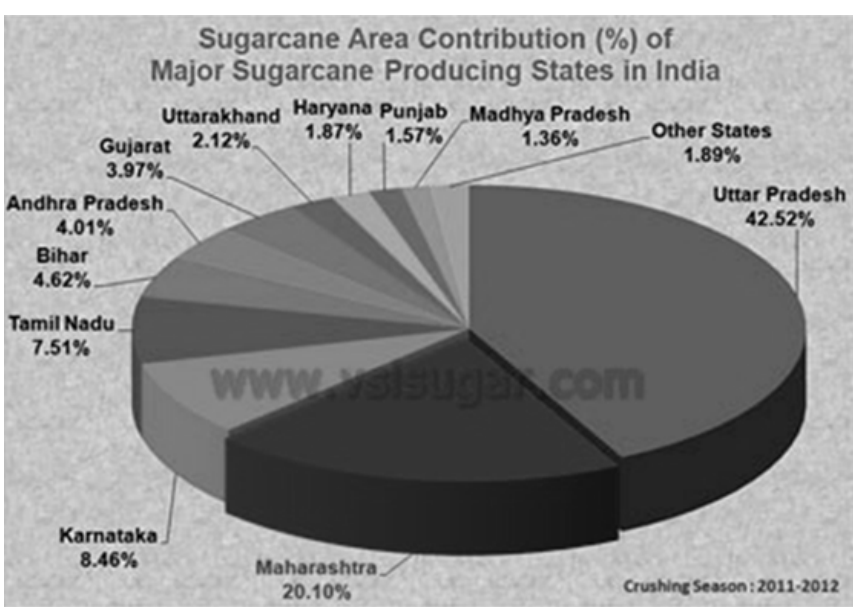

Figure 1: Sugarcane producing states in India.

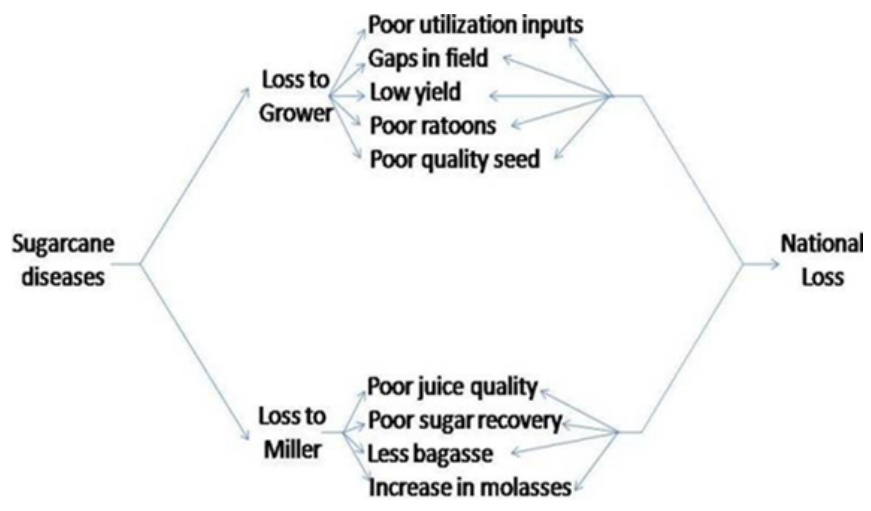

Figure 2: Losses due to sugarcane diseases.

yield and sugar quality [21]. The fungus is sett-borne. The perpetuation of red rot is through infected setts/canes, diseased stubble/debris and by resting propagules in the soil. Annual recurrence of red rot in sugarcane is primarily due to infected seed cane and stubble through which the pathogen is carried over to subsequent crops [22,23]. The role of soil-borne inoculum in the recurrence of disease is perhaps negligible as the fungus is not a true soil borne organism and does not survive in soil for more than 5-6 months [24,25].

The pathogen attacks the cane plant from the very beginning, i.e., germination [26] and cause germination failure or cause death of germinated seedlings. In general, dormant mycelia present in the bud scales are responsible for post-germination infection of young emerging shoots [27].

\section{Dissemination}

Manifestation of red rot varies depending on the nature of infection, time of the season and the prevailing environment. Diagnostic symptoms are observed during monsoon or post monsoon period $[28,29]$. With the advent of pre-monsoon showers, symptoms of the disease start appearing, and with the onset of the monsoon when the weather is most suitable, full manifestation of the disease takes place [10].

The secondary transmission of the fungus during monsoon is mediated through irrigation, rain water, rain splash and results in the infection of mid-rib, lamina, leaf sheath and stalk, while in winter air currents aid in the spread of the pathogen [30,31]. The conidia produced over the rind wash down with water and cause infection through nodes. Dissemination of inoculum by means of wind appears more difficult because of the mucilaginous nature of the spore mass. But the occurrence of the disease in the upper portion of the canes provides an indication of an aerial mode of dispersal of the inoculum. Environmental conditions prevailing during the winter season do not favour the fungus to infect the crop and may not pose any serious threat to infect the cane crop [9] but leads to the development of incipient infections in the nodal region (buds, bud scales, root primordia, etc.). Such infections serve as primary infection when cane is used as seed [26]. Borers also help in the secondary transmission of the pathogen [32].

\section{Mode of infection}

The pathogen mainly infects canes through nodes and main portal of entry are leaf scar, growth ring, root primordia and buds [33-35]. The pathogen can also enter the stalk through root lets, growth cracks and cut ends of the setts [29].

After the fungus invades the tissues of the stalk, the mycelium may spread from cell to cell leads to gum formation in moderately resistant genotypes. More rapid spread can occur through the vascular bundles. Infected internode tissues develop a rot with a characteristic red colour that often contains interspersed areas with normal colour known as "white spots" [36-39]. The disease cycle of red rot is shown in Figure 3.

\section{Favourable conditions for disease development}

- Mean temperature range of 29.4 to $31^{\circ} \mathrm{C}$ is optimum for the development of the disease $[40,41]$.

- $\mathrm{pH}$ 5-6 [42].

- Drought conditions during the initial growth phase [43].

- High atmospheric humidity (90\%).

- Water-logged conditions of the soil.

- Lack of cultural practices that result in the growth of weeds.

- Continuous cultivation of same variety in the field.

- Presence of susceptible varieties in the surroundings.

\section{Etiology}

Division: Eumycota

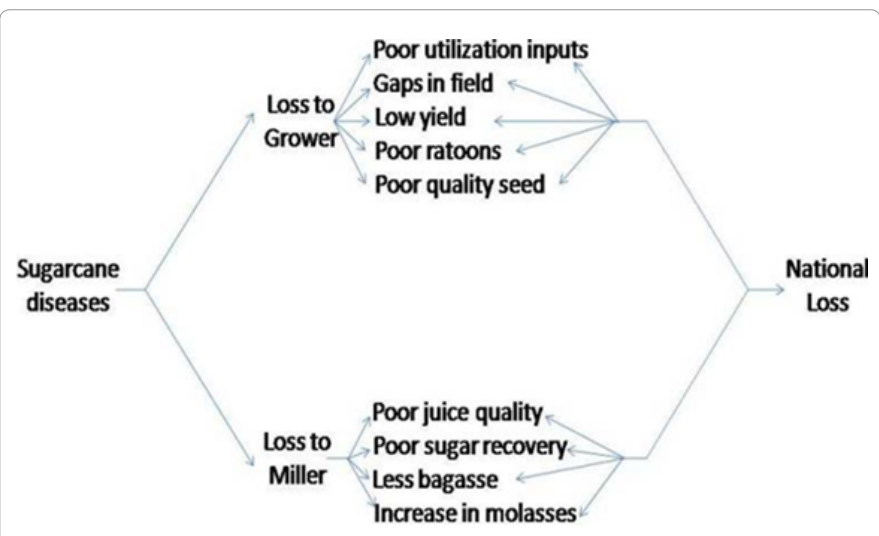

Figure 3: Disease cycle of red rot of sugarcane. 


\section{Sub division: Deuteromycotina}

Class: Coelomycetes

Order: Melanconiales

Family: Melanconiaceae

\section{Genus: Colletotrichum}

\section{Species: falcatum}

The key morphological identification features of C. falcatum fungus are: its mycelium which is both intracellular and intercellular, asexual fruiting bodies known as acervuli (minute, velvety and formed on the surface of the host part), often with setae (dark-pigmented, unbranched, thick-walled sterile hyphae usually pointed at the tip), having hyaline, linear or club shaped conidiophores producing elongated, single celled, thin walled, uninucleate, colourless, sickle shaped (Falcate), slimy conidia having granular protoplasm with a large oil globule, thick walled, greenish black chlamydospores and the presence of appressoria (thick-walled swellings at the end of a hypha or germ tube useful for attaching the fungus to the host surface before penetration of the tissue), presence or absence of the telomorph, colony colour and growth, production of pigments and growth rate which are mostly used for genetic characterization $[9,10,44,45]$.

C. falcatum, a facultative saprophyte, known to produce a phytotoxic metabolite identified as an anthroquinone compound. It has been established that the toxic metabolite is host-specific and produces part of the disease symptoms [46,47]. Its sexual stage known as G. tucumanensis is responsible for the survival of the fungus on decaying leaves and formation of new virulent pathological races which are responsible for the frequent epidemics [26].

Ten races of $C$. falcatum have been reported in India based on host differentials [18]. If a fairly large number of isolates of the fungus obtained from different cane varieties or geographic areas are studied on artificial culture media, considerable variation in the type of growth and colour of the fungus colony usually is seen. Some isolates or races are light gray and form a loose cottony colony, others are dark gray and form a restricted velvety colony while some are intermediate in those respects. If they are inoculated into stalks of sugarcane, they also differ in pathogenicity and their ability to infect and rot the stalks [48]. The light race produced abundant spores and proved more virulent than the dark one. All the previous isolates of $C$. falcatum from India were dark type with sparse sporulation [9].

\section{Symptomatology}

Expression of the disease may vary depending upon nature of infection and prevailing environmental conditions [9]. In the early stages of infection, it is difficult to recognize the presence of the disease in the field as reddening of the internal tissues with interrupted red and white patches, the characteristic symptoms of the disease, develops on the stem only at later stages. Furthermore, latent infection occurs frequently, making visual diagnosis impossible [49].

The first symptoms of the disease are seen when the vegetative growth of the plant is stopped and sucrose formation begins, i.e., after rainy season. The pathogen, C. falcatum Went, can attack any part of the sugarcane plant; be it stalk, leaf, buds or roots. C. falcatum completes its life cycle on the sugarcane leaf and usually the damage to leaf does not pose a serious threat to cane or cause much harm to the plant [10]. Discolouration of the leaves is the first symptom in the field. The spindle leaves ( $3^{\text {rd }}$ and $4^{\text {th }}$ leaf) display drying which withers away at the tips along the margins. This discolouration from tip to the base is continued till all the leaves of the crown wilt [26]. Tiny reddish lesions occur on the upper surface of the lamina with minute red spots in both the directions of the upper surface of the midrib. Infection also resulted in change in the colour of the leaves that become straw coloured in the center and dark reddish brown at the margins with the development of black acervuli. The infected leaves may break at the lesions and hang down.

The most damaging phase of this disease occurs when the pathogen attacks the stalk. Depending on the age of the stalk, time of infection and susceptibility of the cane genotype, it produces different types of symptoms [10]. Typical symptoms of red rot are observed in the internodes of a stalk by splitting it longitudinally. These include the reddening of the internal tissues which are usually elongated at right angles to the long axis of the stalk. Cross-wise white patches are the important diagnostic characters of the disease. The white spots may vary in size and number and sometimes they are so numerous as to give the tissue a mottled appearance [27]. With the advancement of disease, the stalk becomes hollow and covered with white mycelial growth. Later on the rind shrinks longitudinally with the protrusion of minute black, velvety fruiting bodies. The infected cane emits acidic-sour smell while its juice emits alcoholic smell. As sucrose gets converted to glucose and alcohol in diseased cane, it does not set well upon boiling.

\section{Host Resistance}

The factors responsible for determining host resistance against C. falcatum have not been fully understood. Two types of resistance against red rot pathogen have been recognized [9].

\section{Morphological resistance}

It refers to those structures or modification in the plant tissue, which mechanically restrict or prevent the entry or spread of the pathogen in the host tissues. Various parameters viz., thickness of epidermis, cuticle, bud scales, rind, relative abundance of vascular bundles under the rind and the presence of septa in vascular bundles prevents the rapid migration of spores in the plant tissue [32].

\section{Biochemical resistance}

A brown gummy substance is formed in advance of the infection in resistant varieties which seals off further spread of the pathogen in adjoining tissues [32]. On the contrary, gum formation in susceptible varieties takes place after tissue has been infected to a lesser extent. This has been termed as hypersensitive gumming reaction [50].

In resistant varieties it was observed that the level of total phenolics increased after infection and was maintained, while in susceptible varieties, the level of phenolic content dropped after an initial increase [51-53].

Srinivasan and Srivastava et al. $[54,55]$ observed that higher activity of poly phenol oxidase (PPO) and flavone glycosides is linked with red rot resistance. Madan et al. [56] linked the red rot resistance to higher specific activity of Phenylalanine Ammonia lyase (PAL) and Tyrosine Ammonia lyase (TAL). Viswanathan et al. [57] correlated the role of phytoalexin 3- deoxyanthocyanin with red rot resistance.

As pathogen is highly variable in nature, the resistant sugarcane varieties gets prone to red rot within a short time period, therefore detailed investigation is required to understand the true basis of disease resistance at molecular level [9].

\section{Disease Management}

Management of red rot has been a challenging area of work for 
the pathologists and sugarcane breeders. The epiphytotic of the disease depends upon weather conditions, genotypes, presence of virulent pathogen and time for disease development. These factors must be studied in depth so as to achieve effective control of the disease. It has been observed that once the disease has appeared in the field it is impossible to control. Most of the recommended management practices hence are aimed at prophylactic measures to reduce pathogen build up in the field [27]. In view of diversity in the kinds of pathogens, a single method would not be useful to mitigate the losses from red rot [26], hence Integrated Disease Management (IDM) should be practiced. The IDM chart is shown in Figure 4. The following methods in desirable combinations could be adopted for controlling the red rot disease.

\section{Diagnostic measures}

Correct diagnosis of pathogens is the primary requirement in any sound disease management practice [58]. Disease diagnosis and pathogen identification by conventional methods involves isolating the pathogen and characterizing it by inoculation tests [49]. The variability of red rot pathogen was first studied by Edgerton and Moreland [59]. The characterization of pathogen has primarily been based upon variation in colour, conidial size and shape, appressoria, colony characters, host association and sporulation [60-64]. But this phenotypic identification is time consuming, expertise specific and not always fully discriminative [45].

Over the past few decades, immunological methods have increasingly received attention as an alternative or complement to conventional methods [65]. Polyclonal antisera were developed against the C. falcatum proteins and ELISA, DIBA and Western blot methods were standardized for detection of $C$. falcatum in sugarcane [66]. Hiremath and Naik [67] developed a protocol for rapid diagnosis of sugarcane red rot infection by using Dot Immunobinding assay (DIBA) technique. But there is a drawback associated with serological assays that there could be chances of false positives caused by crossreaction of antibodies with plant debris or unrelated organisms [68].

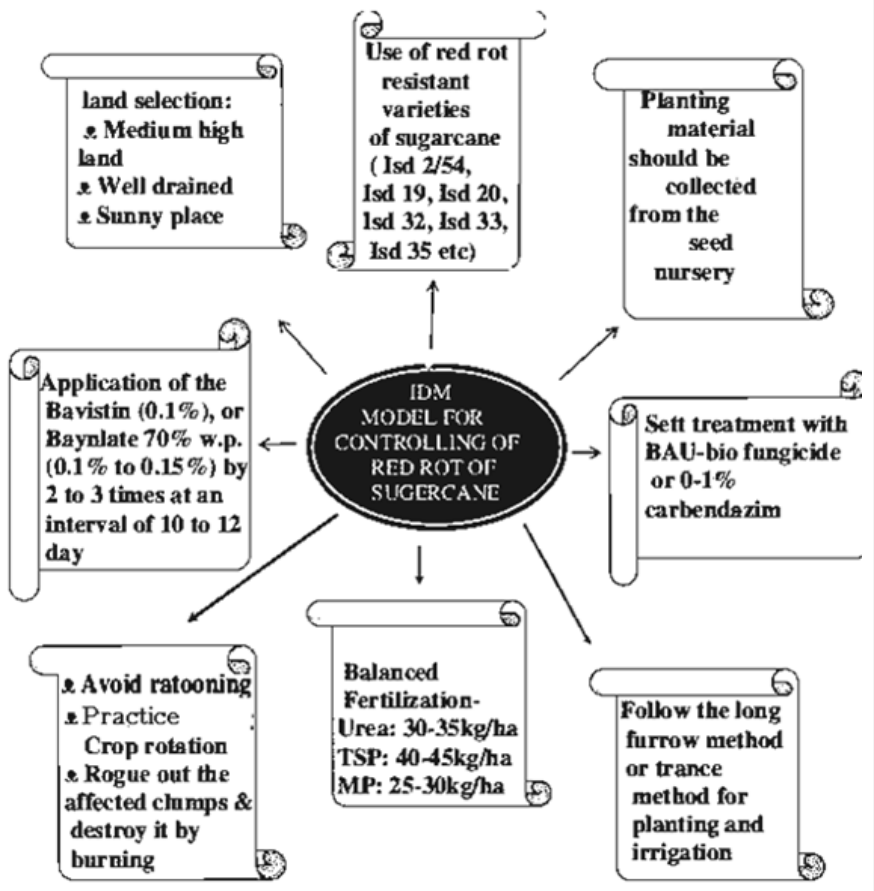

Figure 4: Integrate disease management for controlling of red rot of sugarcane.
Molecular methods based on polymerase chain reaction (PCR) are frequently being used now a day for detecting fungal pathogens in plant tissues [69-73], due to their increased specificity and sensitivity in comparison to the traditional techniques. Variability in C. falcatum isolates have been characterized by using arbitrary marker system such as RAPD [74-77]. Kumar et al. [45] used inter simple sequence repeat (ISSR), universal rice primers (URPs) and RAPD markers to characterize variability among $C$. falcatum isolates. ITS primers were also used to study the variability among pathogen $[78,79]$. Nithya et al. [49] developed SCAR markers specific to races and isolates of $C$. falcatum.

A combination of molecular diagnostic techniques and conventional morphological characterization is a suitable and reliable approach for studying Colletotrichum species/isolates complexes [80,81]. But it is very much difficult to diagnose the dormant infections of the C. falcatum fungus in seed canes under field conditions as red colour develops on stem and leaves at a later stage [82]. It is therefore, important to explore other possibilities for the management of red rot in sugarcane [83].

\section{Resistant varieties}

Effective control of red rot has been mainly through the use of resistant varieties. Even though genetics of inheritance of red rot resistance is not well established, considerable progress has been made in the production of red rot resistant varieties [27]. In India, the breeding work is primarily focused on developing red rot resistant varieties [26]. But as the pathogen is highly variable in nature, therefore, even if a disease resistant variety is released for cultivation, it gets susceptible to red rot disease within 8-10 years because of the development of new more virulent races of the pathogen $[84,85]$.

From the last few decades, molecular diagnostic tools have increasingly been used as an alternative to traditional techniques [65]. Molecular markers could be used as an effective means that can unfold the complex genetics of sugarcane and also aid the breeders in improving the genetic makeup of varieties [86-88]. So far, sugarcane diversity has been studied using ribosomal DNA [89], simple sequence repeats [90]; amplified fragment length polymorphism [91]; restriction fragment length polymorphism [92]; TRAP [93] and random amplified polymorphic DNA [83]. Considerable efforts are going on to identify genes and develop markers associated with red rot resistance.

\section{Legislation (Quarantine)}

Quarantine regulations govern the introduction of plant material from high-risk areas. In India, seed cane is frequently taken from one state to another without any regulatory restriction [26]. Unrestricted movement of seed material has been largely responsible for the spread of red rot in different regions. The recent introduction of the disease in Karnataka and Maharashtra was because seed material of highly susceptible varieties was brought from red rot endemic areas [94]. Hence there is a need for restricting transport of cane from an infected zone to disease free zones. The seed material from outside state is procured only from research stations with proper phytosanitory certificate [9].

\section{Prophylaxis}

Prevention is better than cure hence, healthy cultural practices should be adopted while planting the sugarcane. Use of healthy seeds, crop rotation, field sanitation and efficient drainage have been recommended to reduce inoculum in the field and minimize losses due to the disease. The primary inoculum of the disease mainly comes 
through infected seed material [9] hence; disease free seed nursery should be established in each farm and farmer's field. In this context, seed from heat treated crop or certified nursery will serve the purpose. In addition to this, sanitary measures must be adopted in the field. Crop debris, trash and stubble should be burnt prior to planting [26]. Extremely dry and wet soils should be avoided. Ratooning should not be done in case of heavily infected plant crops. To minimise the soil borne inoculum, crop rotation should be adopted by growing some other crop for 2-3 years. Flow of irrigation water from diseased to healthy plants should be discouraged to avoid the spread of disease through water medium. Long setts should be used for planting. Three or four budded setts are very suitable seed setts for the control of soil born inoculums of redroot [95].

\section{Chemotherapy}

A number of fungitoxicants have been tried against the red rot but a little success is found in controlling this devastating disease. This may be because of impervious nature of rind, presence of fibrous nodes at the cut ends, low solubility of fungicides, lack of broad spectrum fungicides and presence of abundant nutrients in the sett $[9,26]$. Some reduction in red rot incidence has been reported when infected setts were treated with carbendazim and benomyl, which is not commercially produced now for 1-2 hours [96-98]. Chand et al. [97] also reported that Vitavax reduced the red rot incidence in sugarcane. Dip treatment of setts in Agallal (0.5\%) for 15 min was found effective [99]. Bleaching powder was effective in reducing red rot incidence [100]. Soaking of sugarcane setts in $0.25 \%$ suspension of thiophanate methyl and its metabolite carbendazim for $24 \mathrm{~h}$ before planting was found to be effective in controlling debris-borne infection [101]. In a test conducted by Subhani et al. [102] benomyl, folicar, radomil and tilet completely inhibited the growth of fungus (100\% inhibition) while minimum mycelial growth inhibition was observed in case of nimrod. Treatment with topsin $\mathrm{M}$ helps in protecting canes from red rot disease and improving plant yield [103]. In an experiment conducted by Bharadwaj and Sahu [104], bavistin showed complete inhibition of mycelial growth of the $C$. falcatum. Secondary infection of red rot was checked by spraying copper and dithiocarbamate fungicides [105], but negative results were obtained by Sinha and Misra [106].

\section{Thermotherapy}

Heat therapy has been used for controlling sett borne infection of red rot by various workers. Sinha et al. and Singh $[107,108]$ reported complete elimination of sett-borne infection by hot air treatment $\left(54^{\circ} \mathrm{C}\right.$ for $\left.8 \mathrm{~h}\right)$. Some workers have used heat and chemotherapy in combination by incorporating the chemical into the hot water tank for adequate control of red rot [109]. Findings of various workers have proved that moist hot air therapy (MHAT) of seed cane at $54^{\circ} \mathrm{C}$ for $4 \mathrm{hr}$ (R.H. 95-100) was most effective against red rot [110-113]. Ref. [114] reported that moist hot air treatment $\left(54^{\circ} \mathrm{C}-2 \mathrm{~h}\right)$ was more effective than hot water treatment $\left(50^{\circ} \mathrm{C}-2 \mathrm{~h}\right)$ in reducing red rot. Aerated steam treatment at $52^{\circ} \mathrm{C}$ or the soaking of setts in cold running water for $48 \mathrm{~h}$ followed by hot-water treatment $\left(50^{\circ} \mathrm{C}\right.$ for $\left.150-180 \mathrm{~min}\right)$ also helps in eliminating the pathogen from infected setts [29].

\section{Biological control}

Red rot disease of sugarcane was observed to be biologically controlled through Trichoderma harzianum and T. viride [115]. T. harzianum and Pseudomonas spp. possess the ability to protect the crop from soil borne inoculum of red rot and the efficacy is because of the chitinase enzyme produced by them [116]. The findings of ref. [117] clearly supported that ech 42 gene of Trichoderma spp. is responsible for controlling the red rot incidence in sugarcane in an experiment conducted by Singh et al. [118], addition of SA (salicylic acid) has boosted the protection level significantly against red rot disease and helped T. harzianum for inducing systemic resistance in sugarcane.

Ocimum, Ginger, Onion and Garlic were found to inhibit the mycelial growth. It was also examined that the essential oils, viz. Peppermint oil, Mentha oil, Geranium oil, Patchouli oil and Palmaroza oil were effective in inhibiting the growth of mycelia of C. falcatum [104].

In sugarcane, [119] established PGPR (Plant growth promoting rhizobacteria) mediated ISR (Induced systemic resistance) against $C$. falcatum causing red rot disease. The study conducted by Viswanathan et al. [120] indicates a possible role of PR (pathogenesis related) proteins in conferring red rot resistance in sugarcane. The peptides MUC1 60 mer and Purothionins mixture significantly inhibited the mycelial growth and spore germination of C. falcatum [121].

It was showed in an experiment that leaf extracts of Curcuma domestica and Datura metel inhibited the conidial as well as mycelial growth. Smoke of dhup (incense) and tobacco also showed inhibition against conidial germination [122-124].

\section{Conclusion and Future Perspectives}

Red rot disease of sugarcane continues to be a serious threat to production of sugarcane all around the globe. Integrated disease management strategy is the best possible option in controlling this disease, rather than relying upon a single method. An understanding of the pathogen is a pre-requisite for disease management, which could be accomplished by molecular diagnostic tools for a rapid and precise detection of the pathogen in seed cane. Though limited information is available regarding the true basis of disease resistance, molecular tools are now available to identify suitable markers that can be relied upon for supporting the conventional breeding approaches. These biotechnological approaches should be supplemented with different other control measures like quarantine regulations, clean cultural practices, use of chemicals, biocontol agents and heat therapy. In addition to the existing control measures, novel strategies should be thought of to explore the possibility of inducing systemic resistance against the $C$. falcatum. Further with the identification of candidate defense genes, development of transgenic sugarcane with built-in resistance to red rot is to be looked into for the future.

\section{References}

1. Menossi M, Silva-Filho MC, Vincentz M, Van-Sluys MA, Souza GM (2008) Sugarcane Functional: Gene Discovery For Agronomic Trait Development. International Journal of Plant Genomics 2008: 1-11.

2. Da Costa MLM, Amorim LLB, Onofre AVC, De Melo Ljot, De Oliveira MBM, et al. (2011) Assessment of Genetic Diversity In Contrasting Sugarcane Varieties Using Inter-Simple Sequence Repeat (Issr) Markers. American Journal of Plant Sciences 2: 425-432.

3. Food and Agricultural Organization of United Nations: Economic and Socia Department: The Statistical Division 2004.

4. Jayashree J, Selvi A, Nair NV (2010) Characterization of Resistance Gene Analog Polymorphisms In Sugarcane Cultivars With Varying Levels of Red Rot Resistance. Electronic Journal of Plant Breeding 1(4): 1191-1199.

5. Vishwakarma Sk, Kumar P, Nigam A, Singh A, Kumar A (2013) Pokkah Boeng: An Emerging Disease of Sugarcane. Journal of Plant Pathology and Microbiology 4: 170.

6. Mumtaz AS, Nayab DE, Iqbal MJ, Shinwari ZK (2011) Probing Genetic Diversity To Characterize Red Rot Resistance In Sugarcane. Pakistan Journal of Botany 43: 2513-2517.

7. Rott P, Bailey Ra Comstock Jc, Croft Bj, Saumtally AS (2000) A Guide To 
Sugarcane Disease. Cirad. Issct, Cirad Publications Services, Montepellier, France 339.

8. Singh O, Waraitch Ks (1981) Effect of Wilt and Red Rot Induced Disease Stress On Quality Deterioration of Sugarcane. Sugarcane Pathology Newsletter 27: 25-9.

9. Satyavir (2003) Red Rot of Sugarcane - Current Scenario. Indian Phytopathology 56: $245-254$

10. Duttamajumder Sk (2008) Red Rot of Sugarcane. Indian Institute of Sugarcane Research, Lucknow, India.

11. Hussnain Z, Afghan S (2006) Impact of Major Cane Diseases On Sugarcane Yield and Sugar Recovery. Annual Report, Shakarganj Sugar Research Institute, Jhang, Pakistan

12. Sehtiya HI, Phawan AK, Virk KS, Dendsay J (1993) Carbohydrate Metabolism In Relation To Colletotrichum Falcatum In Resistant and Susceptible Sugarcane Cultivars. Indian Phytopathology 46: 83-85.

13. Khan Hmwa, Awais M, Raza W, Zia A (2011) Identification of Sugarcane Lines With Resistance To Red Rot. Pakistan Journal of Phytopathology 23: 98-102.

14. Went FAFC (1893) Het Rood Snot (Summary In English). Archiefvoor De Java Suikerindustrie 1: 265-282.

15. Carvajal F, Edgerton CW (1944) The Perfect Stage of Colletotrichum Falcatum Went. Phytopathology 34: 206-213.

16. Arx JAV, Muller E (1954) Die Gattungen Der Amerosporen Pyrenomyceton (The Genera of Amerosporous Pyrenomyceton), Beiter. (Summary In English). Kryptogamen Flora Der Schweig 11: 195-196.

17. Barber CA (1901) Sugarcane Disease In Godawari and Ganjam Districts. Madras Department of Land Records and Agricultural Bullettin 43: 181-194.

18. Singh N (2008) Sustainable Management of Red Rot Disease of Sugarcane. Indian Sugar 58: 21-30

19. Babu C, Koodalingam K, Natarajan US, Shanthi RM and Govindaraj P (2009) Genetic Enhancement of Sugarcane (Saccharum Sp. Hybrids) For Resistance To Red Rot Disease and Economic Traits. The Journal of Agricultural Sciences 4: $97-107$.

20. Babu C (2010) Pre-Breeding In Sugarcane (Saccharum Sp. Hybrids) For Red Rot Resistance and Economic Traits. Electronic Journal of Plant Breeding 1 : 1024-1034.

21. Rao Gp (2004) Sugarcane Pathology. Oxford and Ibh Publishing Company Uk 2.

22. Butler EJ, Khan AH (1913) Red Rot of Sugarcane. Memoirs of Deptartment of Agriculture, India, Botanical Series 6: 151-178.

23. Agnihotri VP, Budhraja TR, Singh K (1979) Role of Diseased Sett and Soil In The Annual Recurrence of Red Rot In Sugarcane. International Sugar Journal 82: 263-265.

24. Chona BL, Nariani TK (1954) Investigations On The Survival of The Sugarcane Red Rot Fungus In The Compost. Indian Phytopathology 5: 151-157.

25. Singh K, Budhraja TR, Agnihotri VP (1977) Survival of Collatotrichum Falcatum In Soil, Its Portals of Entry and Role of Inoculum Density In Causing Infection. International Sugar Journal 79: 43-44.

26. Agnihotri VP (1996) Current Sugarcane Disease Scenario and Management Strategies. Indian Phytopathology 49: 109-126.

27. Viswanathan R, Sundar AR, Malathi P, Padmanaban P (2011) Red Rot of Sugarcane (Ed., T.R. Shanthy). Sugarcane Breeding Institute, Coimbatore.

28. Agnihotri VP, Singh K (1977) Seed-Piece Transmissible Diseases of Sugarcane and Their Chemical Control. Sugar News 2: 90-95.

29. Singh K, Singh Rp (1989) Red Rot, In: Sugarcane Diseases - Major Diseases (Eds., C. Ricaud, B.T. Egan, A.G. Gillaspie, C.G. Hughes). Elsevier, Amsterdam 169-188.

30. Agnihotri VP (1990) Diseases of Sugarcane and Sugarbeet. Oxford and Ibh Publishing Company Private Limited, New Delhi 483.

31. Singh RP, Lal S (1996) Air-Borne Propagules of Colletotrichum Falcatum Went and Their Role In The Epidemiology of Sugarcane Red Rot. Indian Phytopathology 49(1): 89-91.

32. Edgerton CW (1959) Sugarcane and Its Diseases. Louisiana State University Press, Louisiana, Usa.
33. Steib RJ, Chilton SJP (1951) Infection of Sugarcane Stalks By The Red Rot Fungus Physalospora Tucumanensis Speg. Phytopathology 41: 522-528.

34. Srinivasan KV, Alexander KC (1966) A Study of Mode of Nodal Infection and Occurrence of Dormant Infections of Red Rot. Proceedings of All India Conference On Sugarcane Research and Development Workers 5: 676-684.

35. Singh RP, Lal S, Singh K (1983) Development of Dormant Nodal Infection of Colletotrichum Falcatum Went In Sugarcane. Annual Convention of The Sugar Technologists Association of India 47: 79-90.

36. Abbott EV (1938) Red Rot of Sugarcane. U.S. Department of Agriculture Technical Bulletin 641: 96

37. Edgerton CW (1955) Sugarcane and Its Diseases. Louisiana State University Press, Baton Rouge.

38. Singh K, Singh Rm (1988) Red Rot, In: Ricaud C, Egan BT, Gillaspie AG, Jr. Hughes Disease of Sugarcane - Major Diseases. Elsevier Scientific Publishers, New York 169-188.

39. Yin Z, Hoy JW, Milligan SB (1996) Evaluation and Heritability of Resistance To Sugarcane Red Rot. Phytopathology, 86: 662-667.

40. Singh K, Singh RP, Lal S (1988) Effect of Ambient Temperature On Red Rot Development In Sugarcane. Indian Phytopathology 41: 86-91.

41. Beniwal MS, Satyavir (1991) Effect of Atmospheric Temperature On The Development of Red Rot of Sugarcane. Indian Phytopathology 44: 333-338.

42. Satyavir KA, Kumar A, Raj K (2002) Fungal Diseases of Sugarcane. In: Gupta VK, Paul YS (ed) Diseases of Field Crops Indus Publishing Company, New Delhi.

43. Yin Z, Hoy JW (1997) Effect of Stalk Desiccation On Sugarcane Red Rot. Plant Disease 81: 1247-1250.

44. Bailey JA, Jeger MJ (1992) Colletotrichum: Biology, Pathology and Control. Cab International, Wallingford, Uk.

45. Kumar N, Jhang T, Satyavir, Sharma TR (2010) Molecular and Pathological Characterization of Colletotrichum Falcatum Infecting Subtropical Indian Sugarcane. Journal of Phytopathology 154: 260-267.

46. Olufolaji DB, Bambgoye AO (1986) Production, Partial Characterization and Bioassay of Toxins From Physalospora Tucumanensis Speg., Sugarcane Red Rot Fungus. Cryptogamie-Mycologie 7: 331-334

47. Malathi P, Viswanathan R, Padmanaban P, Mohanraj D, Sundar AR (2002) Microbial Detoxification of Colletotrichum Falcatumtoxin. Current Science 83: 745-749.

48. Abbott EV (1953) Red Rot of Sugarcane. Yearbook of Agriculture 536-539.

49. Nithya K, Bukhari Kaim, Valluvaparidasan V, Paranidharan V, Velazhahan R (2012) Molecular Detection of Colletotrichum Falcatum Causing Red Ro Disease of Sugarcane (Saccharum officinarum) Using A Scar Marker. Annals of Applied Biology 160: 168-173.

50. Srinivasan KV, Bhat NR (1961) Red Rot of Sugarcane: Criteria For Grading Resistance. Journal of Indian Botanical Society 40: 566-577.

51. Singh K, Singh RP, Agnihotri VP (1976) Phenolics In Relation To Sugarcane Resistance Against Red Rot Disease. Sugarcane Pathologists Newslette 15/16: 37-41.

52. Beniwal MS, Taneja AD, Satyavir, Khirbat SK (1988) Phenols In Relation To Sugarcane Resistance Against Red Rot Disease. Bharatiya Sugar 13: 49-52.

53. Jaglan Bs (1990) Studies on Some Morphological and Biochemical Factors In Relation To Red Rot Resistance In Sugarcane. M.Sc. Thesis. Haryana Agricultural University, Hisar.

54. Srinivasan KV (1969) Physiology of Disease Resistance In Sugarcane With Particular Reference To Red Rot. Proceedings, Indian Academy of Science 59: $120-132$

55. Srivastava BL, Solomon S (1990) Biochemical Analysis of Induced Mutant of Sugarcane (Saccharum Sp). International Symposium On Genetic Engineering and Plant Tissue In Relation To Disease and Pest Resistance of Crop Plants, Tnau, Coimbatore.

56. Madan VK, Soni N, Nigar M, Soloman S, Agnihotri VP (1991) Enzyme Activity and Cane Genotype Resistance To Red Rot. Sugarcane 2: 6-8.

57. Viswanathan R, Mohanraj D, Padmanbhan P, Alexander Kc (1996) Accumulation of 3-Deoxyanthocyanidin. Phytoalexins, Luteolinid In and Epigenidin In 
Sugarcane In Relation To Red Rot Disease. Indian Phytopathology 49: 174175

58. Sundar AR, Barnabas EL, Malathi P, Viswanathan R (2012) A Mini-Review On Smut Disease of Sugarcane Caused By Sporisorium Scitamineum, In: Botany (Ed., J. Mworia). Intech.

59. Edgerton CW, Moreland CC (1920) Effect of Fungi On The Germination of Sugar Cane. Baton Rouge, La.: Agricultural Experiment Station of The Louisiana State University and A., M. College.

60. Chona BL, Padwick GW (1942) More Light on The Red Rot Epidemic. Indian Farming 3: 70-73.

61. Rafay SA (1950) Another Strain of Physalospora Tucumnensis. Curren Science 19: 385-386.

62. Rafay SA, Singh VB (1957) A New Strain of Glomerella Tucumanensis. Current Science 26: 19-20.

63. Sutton BC (1992) The Genus Glomerella and Its Anamorph Colletotrichum, In: Colletotrichum: Biology, Pathology and Control (Eds., J.A. Bailey, M.J. Jeger). Cab International. Wallingford, U.K. 1-26.

64. Abbas H, Anwar SA, Javed N, Iqbal MA, Abid N (2010) Morphological Variability Among Isolates of Colletotrichum Falcatum Went. Infecting Four Cultivars of Sugarcane. Pakistan Journal of Phytopathology 22: 101-104.

65. Schaad NW, Frederick RD, Shaw J, Schneider WI, Hickson R, et al. (2003) Advances In Molecular-Based Diagnostics In Meeting Crop Biosecurity and Phytosanitary Issues. Annual Review of Phytopathology 41: 305-324.

66. Viswanathan R, Samiyappan R, Padmanaban P (1998) Specific Detection of Colletotrichum Falcatum In Sugarcane By Serological Techniques. Sugar Cane 3: 18-23.

67. Hiremath L, Naik GR (2004) Rapid Diagnosis of Sugarcane Red Rot By DotImmunobinding Assay (Diba) Technique. Indian Journal of Biotechnology 3 : $542-545$

68. De Haan L, Numansen A, Roebroeck E, Van Doorn J (2000) Pcr Detection of Fusarium Oxysporum SP. Gladioli Race 1, Causal Agent of Gladiolus Yellows Disease, From Infected Corms. Plant Pathology 49: 89-100.

69. Bonants P, Hagenaar-De Weerdt M, Van Gent-Pelzer M, Cooke D, Duncan $J$ (1997) Detection and Identification of Phytophthora Fragariae Hickman By The Polymerase Chain Reaction. European Journal of Plant Pathology 103 345-355.

70. Zhang AW, Hartman GL, Curio-Penny B, Pedersen WL, Becker KB (1999) Molecular Detection of Diaporthe Phaseolorum and Phomopsis Longicolla From Soybean Seeds. Phytopathology 89: 796-804.

71. Kong P, Hong CX, Jeffers SN, Richardson PA (2003) A Species-Specific Polymerase Chain Reaction Assay For Rapid Detection of Phytophthora Nicotianae In Irrigation Water. Phytopathology 93: 822-831.

72. Shen G, Wang YC, Zhang WI, Zheng XB (2005) Development of A Pcr Assay For The Molecular Detection of Phytophthora Boehmeriae In Infected Cotton. Journal of Phytopathology 153: 291-296.

73. Wang Y, Zhang W, Wang Y, Zheng X (2006) Rapid and Sensitive Detection of Phytophthora Sojae In Soil and Infected Soybeans By Species-Specific Polymerase Chain Reaction Assays. Phytopathology 96: 1315-1321.

74. Madan VK, Bikas M, Ansari MI, Srivastava A, Soni N, et al. (2000) Rapd-Pcr Analysis of Molecular Variability In The Red Rot Pathogen (Colletotrichum Falcatum) of Sugarcane. Sugarcane International 3: 5-8.

75. Mohan Raj D, Padmanabhan P, Karunakaran M (2002) Association of Phytotoxin Produced By Colletotrichum Falcatum Went In The Red Rot Disease of Sugarcane. Sugarcane 5: 21-23.

76. Suman A, Lal S, Shasany AK, Gaur A, Singh P (2005) Molecular Assessment of Diversity Among Pathotypes of Colletotrichum Falcatum Prevalent In SubTropical Indian Sugarcane. World Journal of Microbiology and Biotechnology 21: $1135-1140$

77. Saksena P, Vishwakarma SK, Tiwari AK, Singh A, Kumar A (2013) Pathologica and Molecular Variation In Colletotrichum Falcatum Went Isolates Causing Red Rot of Sugarcane In The Northwest Zone of India. Journal of Plant Protection Research 53: 37-41.

78. Malathi P, Viswanathan R, Sundar AR, Prakasam N, Padmanaban P, et al. (2010) Variability Among Colletotrichum Falcatum Pathotypes Used For
Screening Red Rot Resistance In Sugarcane. Sugarcane International 28: 47 52.

79. Singh D, Tiwari AK, Mall S, Shukla B, Ahmad Iz, et al. (2012) Morphological and Molecular Diversity Among C. FalCatum Isolates Causing Red Rot Disease of Sugarcane In Uttar Pradesh. 10th Pathology Workshop, Nanning, China 9.

80. Cannon Pf, Bridge PD, Monte E (2000) Linking The Past, Present and Future of Colletotrichum Systematics, In: Colletotrichum Host Specificity, Pathology and Host Pathogen Interaction. (Eds., D. Prusky, S. Freeman, M.B. Dickman). Aps Press, St Paul, Minnesota, Usa 1-20.

81. Abang MM (2003) Genetic Diversity of Colletotrichum Gloeosporioides Penz Causing Anthracnose Disease of Yam (Dioscorea Spp.) In Nigeria. Bibliotheca Mycologia 197: 20-33.

82. Viswanathan R, Samiyappan R (2002) Induced Systemic Resistance By Fluorescent Pseudomonads Against Red Rot Disease of Sugarcane Caused By Colletotrichum Falcatum. Crop Protection 21: 1-10.

83. Alvi AK, Iqbal J, Shah AH, Pan YB (2008) Dna Based Genetic Variation Fo Red Rot Resistance In Sugarcane. Pakistan Journal of Botany 40: 1419-1425.

84. Chona BI, Hingorani MK (1950) Comparative Studies of Certain Isolates of Colletotrichum Falcatum In The United States. Science 31: 717-718.

85. Yadav RI (2006) Research Vision To Manage Red-Rot Disease of Sugarcane In India. Sugar Tech 8: 99-100.

86. D'hont A, Rao PS, Feldmann P, Grivet L, Islam FN, et al. (1995) Identification and Characterisation of Sugarcane Intergeneric Hybrids, Saccharum officinarum $\times$ Erianthus Arundinaceus, With Molecular Markers and Dna In Situ Hybridisation. Theoretical and Applied Genetics 91: 320-326.

87. Bundock PC, Eliott FG, Ablett G, Benson AD, Casu RE, et al. (2009) Targeted Single Nucleotide Polymorphism (Snp) Discovery In A Highly Polyploid Plant Species Using 454 Sequencing. Plant Biotechnology Journal 7: 347-354.

88. Parida Sk, Sanjay KK, Sunita K, Dalal V, Hemaprabha G, et al. (2009) Informative Genomic Microsatellite Markers For Efficient Genotyping Applications In Sugarcane. Theoretical and Applied Genetics 118: 327-338.

89. Glaszmann Jc, Lu Yh, Lanand C (1990) Variation of Nuclear Ribosomal Dna In Sugarcane. Journal of Genetics and Breeding 44: 191-198.

90. Cordeiro GM, Taylor GO, Henry RJ (2000) Characterization of Microsatellite Markers From Sugarcane (Saccharum Sp.) A Highly Polyploid Species. Plant Science 155: 161-168.

91. Butterfield MK, Hont D, Berding N (2001) The Sugarcane Genome: A Synthesis of Current Understanding, and Lessons For Breeding and Biotechnology Proceedings of South African Sugar Technology Association 75: 1-5.

92. Coto O, Cornide MT, Calvo D, Canales E, D'hont A, et al. (2002) Genetic Diversity Among Wild Sugarcane Germplasm From Laos Revealed With Markers. Euphytica 123: 121-130.

93. Alwala S, Kimbeng CA, Gravois KA, Bischoff KP (2006) Trap A New Tool For Sugarcane Breeding: Comparison with Aflp and Coefficient of Parentage. Journal American Society of Sugar Cane Technologists 26: 62-87.

94. Anonymous (1998) Proceedings and Recommendations. All India Coordinated Project On Sugarcane, I.I.S.R., Lucknow.

95. Anwar MS, Khan HWA, Munir M, Chattha AA, Zia A (2010) Integrated Contro Strategies For Sugarcane Disease. Pakistan Sugar Journal 25: 8-10.

96. Anzalone Jr L (1970) Air Pressure Incorporation of Fungicides Into Short Stalk Sections of Sugarcane For The Control of Red Rot. Phytopathology 60: 741 742 .

97. Chand JN, Dang JK, Kapoor JR (1974) Systemic Chemicals As Sett Protects Ants. Science and Culture 40: 69-70.

98. Waraitch KS (1983) Control of Red Rot of Sugarcane With Systemic Fungicides. Indian Journal of Mycology and Plant Pathology 13: 343-345.

99. Lewin H, Natarajan S, Rajan Sd (1976) Control of Sugarcane Red Rot (Physalospora Tucumanensis Speg.) by Chemotherapy. Sugarcane Pathologists Newsletter 17: 17-20.

100. Agnihotri VP, Singh N, Lal R, Singh V (1995) Management of Red Rot Disease of Sugarcane. Proceedings of National Seminar On Strategies For Research and Management of Red Rot, Indian Institute of Sugarcane Research Lucknow 294-312. 
Citation: Sharma R, Tamta S (2015) A Review on Red Rot: The "Cancer” of Sugarcane. J Plant Pathol Microbiol S1: 003. doi:10.4172/2157-7471. S1-003

101. Malathi $P$, Padmanaban $P$, Viswanathan $R$, Mohanraj $D$, Sundar AR (2004) Efficacy of Thiophanate Methyl Against Red Rot of Sugarcane. Acta Phytopathologica Et Entomologica Hungarica 39: 39-47.

102. Subhani MN, Chaudhry MA, Khaliq A, Muhammad F (2008) Efficacy of Various Fungicides Against Sugarcane Red Rot (Colletotrichum Falcatum). International Journal of Agriculture and Biology 10: 725-7.

103.Khan SB, Shahid M, Safurehman, Mustafa A (2009) Control of Red Rot Disease of Sugarcane Through Screening of Varieties and Seed Dressing Fungicides. Pakistan Journal of Phytopathology 21: 61-65.

104. Bharadwaj N, Sahu RK (2014) Evaluation of Some Fungicides, Botanicals and Essential Oils Against The Fungus Colletotrichum Falcatum Causing Red Rot of Sugarcane. The Bioscan 9: 175-178.

105. Kirtikar, Verma Hs (1963) Role of Chemicals In Sugarcane Disease Control. Indian Sugar 13: 139-141.

106. Sinha OK, Misra SR (1979) Assessment of Tolerance Standard For Red Rot Infection In Sugarcane Seed-Pieces. Annual Report, lisr, Lucknow.

107. Singh K (1973) Hot Air Therapy Against Red Rot of Sugarcane. Plant Disease Reporter 57: 220-222.

108. Joshi NC (1954) Hot Water Treatment of Setts For The Control of Red Rots and Smut Diseases of Sugarcane. Indian Sugar Ns 4: 2.

109.Agnihotri VP (1983) Diseases of Sugarcane. Oxford and Ibh Publishing Company Private Limited, New Delhi 373.

110. Srivastava NSL, Singh K, Sharma MP (1977) The I.I.S.R. Moist Hot Air Treatment Plant For Seed Cane. Sugar News 9: 96-102.

111. Singh K, Misra SR, Shukla US, Singh RP (1980) Moist Hot Air Therapy of Sugarcane: Control of Sett-Borne Infections of Gsd, Smut and Red Rot. Sugar Journal 43: 26-28.

112. Dhillon PS, Kanwar RS, Bedi JS (1983) Effect of Moist Hot Air Treatment On The Control of Gsd and Rsd and Productivity of Sugarcane. Indian Sugar Crops Journal 9: 3-4.

113. Agnihotri VP (1984) Control of Leaf Scald of Sugarcane By Streptomycin and Heat Therapy. Indian Sugar Crops Journal 10: 17-18.
114. Anonymous. 1980. Proceedings and Recommendations. All India Coordinated Project On Sugarcane, I.I.S.R., Lucknow.

115. Singh V, Srivastava RL, Awasthi SK, Joshi BB (2008) Biological Control of Red Rot Disease of Sugarcane Through Trichoderma Harzianum and Trichoderma Viride. Indian Phytopathology 61: 486-491.

116. Malathi P, Viswanathan R (2013) Role of Microbial Chitinase In The Biocontro of Sugarcane Red Rot Caused By Colletotrichum Falcatum Went. European Journal of Biological Sciences 6: 17-23.

117. Singh RK, Kumar P, Tiwari NN, Singh SP, Tiwari AK, et al. (2013) Role of Endochitinase Gene and Efficacy of Trichoderma Against Colletotrichum Falcatum Went. Causing Red Rot Disease In Sugarcane. Sugar Tech 16 180-188.

118. Singh V, Singh PN, Yadav RL, Awasthi SK, Joshi Bb (2010) Increasing The Efficacy of Trichoderma Harzianum For Nutrient Uptake and Control of Red Rot In Sugarcane. Journal of Horticulture and Forestry 2: 66-71.

119. Viswanathan R, Samiyappan R (1999) Induction of Systemic Resistance By Plant Growth Promoting Rhizobacteria Against Red Rot Disease Caused By Collectotrichum Falcatum Went In Sugarcane. Proceedings of Sugar Technology Association of India 61: 24-39.

120. Viswanathan R, Malathi $P$, Sundar AR, Aarthi S, Premkumari SM, et al. (2005) Differential Induction of Chitinases and Thaumatin-Like Proteins In Sugarcane In Response To Infection By Colletotrichum Falcatum Causing Red Rot Disease. Journal of Plant Diseases and Protection 112: 417-425.

121. Edward A, Dusane DH, Melchias G, Daninigo V, Silambarasan S, et al (2013) Evaluation of Antifungal Activity of Peptides and Enzymes Against The Sugarcane Red Rot Pathogen, Colletotrichum Falcatum. Middle-East Journal of Scientific Research 15: 748-756.

122. Imtiaj A, Alam SM, Islam Akmr, Alam S, Lee TS (2007) In Vitro Studies On Colletotrichum Falcatum The Causal of Red Rot Disease of Sugarcane. American-Eurasian Journal of Agricultural and Environmental Sciences 2: 511-517.

123. Vasantdada Sugar Institute: Sugar Statistics, India.

124. Idm Model of Red Rot of Sugarcane.
This article was originally published in a special issue, Plant Pathology handled by Editor(s). Dr. Tadayuki Iwase, Jikei University School of Medicine 